\title{
Peran Badan Penasehat Pembinaan dan Pelestarian Perkawinan dalam Memberikan Bimbingan Pra Nikah Guna Mewujudkan Keluarga Sakinah Mawaddah dan Rahmah
}

\author{
Vinia Ayu Septiyani \& Muzaki
}

\begin{abstract}
Abstrak
Pada dasarnya setiap pernikahan memiliki keinginan menjadi keluarga yang sakinah, mawaddah, dan rahmah. Dengan adanya bimbingan pra nikah sebagai bekal pengetahuan mengenai pernikahan untuk calon pasangan yang diselenggarakan oleh BP4 Kecamatan Jamblang di harapkan setiap keluarga bisa menjadi keluarga yang harmonis atau keluarga yang sakinah, mawaddah, dan rahmah. Penelitian ini bertujuan untuk mengetahui: 1) Peran BP4 dalam memberikan bimbingan pra nikah dalam mewujudkan keluarga sakinah mawaddah dan rahmah, 2) Metode yang digunakan BP4 dalam mewujudkan keluarga sakinah mawaddah dan rahmah, 3) Dampak bimbingan pra nikah dalam mewujudkan keluarga sakinah mawaddah dan rahmah, di KUA Kecamatan Jamblang. Hasil dari penelitian ini menunjukkan bahwa peranan BP4 sangat penting dalam memberikan bimbingan pra nikah guna mewujudkan keluarga sakinah mawaddah dan rahmah pada calon pengantin di KUA Kecamatan Jamblang. Dampak dari bimbingan pranikah di KUA Kecamatan Jamblang calon pasangan dapat memahami materi tentang bagaimana cara membina keluarga yang baik serta meningkatkan kualitas perkawinan dan dapat mengurangai angka perceraian.
\end{abstract}

Kata Kunci: Peran BP4, Keluarga sakinah mawadah dan rahmah, Bimbingan pra nikah.

\section{PENDAHULUAN}

Manusia diciptakan Allah swt mempunyai naluri manusiawi yang perlu mendapatkan pemenuhan. Pemenuhan naluri manusiawi manusia yang antara lain keperluan biologisnya termasuk aktivitas hidup, yang mencangkup kebutuhan lahir maupun batin. Allah swt mengatur hidup manusia dengan aturan perkawinan. Pernikahan adalah ikatan lahir batin antara pria dan wanita yang punya tujuan untuk membentuk keluarga yang bahagia dan sejahtera.

Pernikahan juga merupakan ikatan suci yang terkait dengan keyakinan dan keimanan kepada Allah SWT. Jadi pernikahan tidak sekedar keinginan seorang saja, akan tetapi ada ikatan ibadah dalam sebuah pernikahan. Dengan demikian pernikahan harus dijaga dengan dengan baik sehinga bisa abadi dan apa yang menjadi tujuan pernikahan dalam islam yakni terwujudnya keluarga yang sakinah 
sehingga akan melahirkan adanya ketentraman dan kebahagiaan hidup, sebagaimana Firman Allah surat Q.S. Ar-Rum: 21:

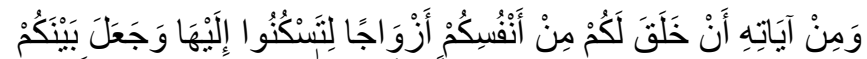

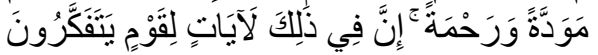

"Dan diantara tanda-tanda kekuasaan-Nya ialah Dia menciptakan untukmu isteri-isteri dari jenismu sendiri, supaya kamu cenderung dan merasa tenteram kepadanya, dan dijadikan-Nya diantaramu rasa kasih sayang.Sesungguhnya pada yang demikian itu benar-benar terdapat tanda-tanda bagi kaum yang berfikir.(Departemen Agama Islam RI, Al-Qur'an dan terjemahannya, 2007 : 572)

Menurut Undang-Undang Nomor 1 Tahun 1974 pengertian dan tujuan perkawinan terdapat dalam satu pasal, yaitu Bab 1 Pasal 1 menetapkan bahwa "perkawinan adalah ikatan lahir batin antara seorang pria dengan seorang wanita sebagai suami istri dengan tujuan membentuk rumah tangga, keluarga yang bahagia dan kekal berdasarkan Ketuhanan Yang Maha Esa". Dengan demikian jelas bahwa diantara tujuan pernikahan adalah membentuk sebuah rumah tangga yang sakinah, mawaddah rahmah. (Undang-Undang Nomor 1 tahun 1974 Tentang Perkawinan)

Tujuan perkawinan pada umumnya tergantung pada masing-masing individu yang akan melaksanakanya, karena lebih bersifat subyektif. Tetapi tujuan perkawinan menurut agama islam ialah untuk memenuhi petunjuk agama dalam rangka mendirikan keluarga yang harmonis, sejahtera dan bahagia. Harmonis dalam menggunakan hak dan kewajiban anggota keluarga. Sejahtera artinya terciptanya ketenangan lahir batin, disebabkan terpenuhnya keperluan hidup dan batinnya, sehingga timbulah kebahagiaan yakni kasih sayang antara anggota keluarga. Selain itu perkawinan juga bertujuan untuk mewujudkan kehidupan rumah tangga yang sakinah mawaddah rahma. (Zainudin Ali, $2006: 8$ )

Permasalahan dan ujian dalam rumah tangga selalu melekat dalam keluarga, bahkan tidak sedikit yang tergoyahkan atau bahkan mengalami kehancuran dalam rumah tangganya, setiap bulan perceraian cenderung selalu terjadi karena ada beberapa faktor yang menjadi alasan terjadinya perceraian. Akan tetapi pada kenyataanya dalam keluarga, konflik seakan-akan merupakan bagian dari kehidupan rumah tangga. Ada konflik yang kadarnya rendah, ada pula yang kadarnya tinggi yang bisa menjurus pada perceraian dan kehancuran rumah tangga. Menurut kenyataan banyak perkawinan yang tidak mencapai cita-cita sebagaimana diharapkan kedua pasangan (suami istri). Ini bisa diamati dari putusan atau penetapan perceraian yang didaftarkan di Kantor Urusan Agama.

Oleh sebab itu, untuk membantu menumbuhkan kesadaran calon pasangan dalam upaya membangun keluarga sakinah dibutuhkan peranan dari pemerintah melalui bimbingan pra nikah oleh BP4 yang bernaung di Kantor Urusan Agama. Dengan adanya keterlibatan dari pemerintah melalui bimbingan pra nikah, 
masyarakat akan mendapatkan pelayanan dan pengetahuan tentang persiapan menghadapi pernikahan dengan mudah. Dengan adanya bimbingan pra nikah maka calon pasangan selain mendapatkan pengetahuan tentang bagaimana mewujudkan keluarga sakinah tetapi juga secara mental atau fisik lebih siap dari sebelumnya.

Bimbingan pra nikah merupakan prosedur pelatihan berbasis keterampilan dan pengetahuan yang menyediakan informasi mengenai pernikahan yang dapat bermanfaat dalam mempertahankan dan meningkatkan hubungan pasangan yang akan menikah atau setiap keluarga yang memperlukan bimbingan agar menjadi keluarga yang sakinah. Bimbingan pra nika yang juga dikenal dengan program persiapan pernikahan dilakukan oleh seorang ahli yaitu seorang penyuluh. Dengan adanya bimbingan pra nikah, diharapkan tujuan dari pernikahan yang dilakukan oleh pasangan suami dan istri bisa di pahami dan dijalankan dengan baik oleh pasangan suami istri. Sehingga terbentuknya keluarga yang diharapkan yaitu keluarga yang sakinah mawaddah rahmah.

Berdasarkan data yang ada di KUA Jamblang jumlah peserta yang mengikuti bimbingan pra nikah berjumlah 15 pasangan calon pengantin. Bimbingan pra nikah wajib diikuti oleh setiap pasangan calon pengantin agar calon pasangan dapat mengetahui bagaimana cara dalam membentuk suatu keluarga yang sakinah. Tetapi dalam kenyataan ada beberapa pasangan calon pengantin yang tidak mengikuti bimbingan pranikah disebabkan karena salah satu pasangan calon pengantin berhalangan hadir dan tidak adanya kesadaran masyarakat terhadap pentingnya mengikuti bimbingan pranikah.

Dengan demikian patut diuji sejauhmana bimbingan pra nikah yang dilakukan BP4 di Kantor Urusan Agama jamblang untuk mengurangi terjadinya perceraian dengan mewujudkan keluarga sakinah mawaddah rahmah. Berdasarkan permasalahan tersebut diatas, peneliti ingin mewujudkan keluarga sakinah mawaddah rahmah melalui BP4 dan tertarik untuk mengadakan penelitian dengan judul "Peran Badan Penasehat Pembinaan dan PelestarianPerkawinan Dalam Memberikan Bimbingan Pra Nikah Guna Mewujudkan Keluarga Sakinah Mawaddah dan Rahmah di KUA Kecamatan Jamblang Kabupaten Cirebon.

\section{LANDASAN TEORI}

Peranan adalah suatu perbuatan seseorang dengan cara tertentu dalam usaha menjalankan hak dan kewajibannya sesuai dengan status yang dimilikinya dan seseorang dapat dikatakan berperan jika ia telah melaksanakan hak dan kewajibannya sesuai dengan status sosialnya dalam masyarakat (Abdul Syani, 2012: 94).

BP4 merupakan singkatan dari Badan Penasehat Pembinaan dan Pelestarian Perkawinan adalah merupakan suatu organisasi yang bersifat semi resmi sebagai penunjang tugas Kementrian Agama dalam bidang perkawinan serta bertujuan untuk mempertinggi mutu perkawinan dan mewujudkan keluarga atau rumah tangga bahagia, sejahtera dan kekal menurut ajaran Islam. (Taufik, 2013 : 4) 
Berdasarkan hasil Munas BP4 tahun 2009 menyatakan bahwa BP4 sebagai organisasi mandiri dan profesional yang bersifat sosial keagamaan sebagai mitra kerja Kementrian Agama dalam mewujudkan keluarga sakinah mawaddah rahmah.

Dengan demikian, BP4 merupakan salah satu organisasi yang berperan sebagai mitra kerja Kementrian Agama yang bersifat profesional dan tidak resmi yang bertujuan untuk mempertinggi mutu perkawinan dan mewujudkan keluarga sakinah dan kekal menurut ajaran Islam. Dengan adanya BP4 maka calon pasangan dipermudah untuk mengetahui atau mendapatkan ilmu pengetahuan tentang bagaimana cara menjadi keluarga yang sakinah mawaddah rahmah.

Tujuan dibentuknya BP4 untuk mempertinggi dan penerangan mengenai mutu perkawinan guna mewujudkan keluarga sakinah menurut ajaran Islam untuk mencapai masyarakat dan bangsa yang maju, mandiri, bahagia sejahtera maupun spiritual dengan:

1. Meningkatkan kualitas perkawinan dan kehidupan berkeluarga yang sakinah, mawaddah rahmah.

2. Menurunkan angka perceraian dengan meningkatkan pelayanan terhadap keluarga bermasalah melalui kegiatan konseling, mediasi dan advokasi.

3. Menguatkan kapasitas kelembagaan dan SDM (Sumber Daya Manusia) BP4 dalam rangka mengoptimalkan program dan mencapai tujuan.

4. Memberikan penyuluhan tentang peraturan perundang-undangan yang berkaitan dengan keluarga.

5. Mengembangkan jaringan kemitraan dengan instansi atau lembaga yang memiliki misi dan tujuan yang sama.

Peran BP4 kaitannya dengan perkawinan adalah memberikan penasehatan melakukan pembinaan dan membantu dalam pelestarian perkawinan. BP4 juga sebagai wadah atau lembaga konsultasi dan mediasi terhadap pasangan suami istri yang menghadapi masalah rumah tangga. BP4 lewat peran seorang konsultannya memberikan penasehatan dan membantu mengarahkan calon pasangan untuk memperoleh solusi untuk mengatasi problem keluarga, perselisihan yang terjadi dalam keluarga sedapat mungkin dibantu upaya penyelesaiannya, sehingga tidak berlarut-larut dan tidak berakhir dengan perceraian (Anggaran Dasar / Anggaran Rumah Tangga BP4).

Upaya dan usaha BP4 mewujudkan keluarga yang sakinah mawaddahrahmah adalah sebagai berikut:

1. Memberikan bimbingan, penasehatan dan penerangan mengenai nikah, talak, dan rujuk kepada masyarakat, baik perorangan maupun kelompok.

2. Memberikan bimbingan tentang peraturan perundang-undangan yang berkaitan dengan keluarga.

3. Memberikan bantuan mediasi kepada para pihak yang berperkara di pengadilan agama, dimulai bulan April 2014, sesuai memorandum kesepahaman penyelenggaraan pelaksanaan mediator No. W.12 A1/89/KHK.05/IV/2014, No. 04/D.12/BP4/IV/2014. 
4. Memberikan bantuan advokasi dalam mengatasi masalah perkawinan, keluarga dan perselisihan rumah tangga di peradilan agama.

5. Menyelenggarakan kursus calon atau pengantin, penataran atau pelatihan, diskusi seminar dan kegiatan-kegiatan sejenis yang berkaitan dengan perkawinan dan keluarga.

6. Meningkatkan upaya pemberdayaan ekonomi keluarga serta upaya lain yang dipandang bermanfaat untuk kepentingan organisasi serta bagi kebahagiaan dan kesejahteraan keluarga.

Upaya dan usaha tersebut di atas merupakan rangkaian upaya dan usaha yang dilakukan BP4 untuk mewujudkan keluarga sakinah mawaddah rahmah. Dalam pelaksanaannya upaya dan usaha tersebut dilaksanakan di berbagai program yang ada di BP4 itu sendiri. Serta dapat memberikan penasehatan dan membantu mengarahkan calon pasangan untuk memperoleh solusi untuk mengatasi problem keluarga, perselisihan yang terjadi dalam keluarga sedapat mungkin dibantu upaya penyelesaiannya agar tidak berlarut-larut.

Bimbingan secara etimologis. Kata bimbingan menurut terjemahan dari bahasa Inggris "guidance" yang berarti pemberian petunjuk, pemberian bimbingan atau tuntunan kepada orang lain yang membutuhkan (Samsul, Munir, 2013: 3). Bimbingan merupakan bantuan yang diberikan kepada individu, untuk mengembangkan kemampuan-kemampuannya dengan baik agar individu tersebut dapat memecahkan masalahnya sendiri dan dapat mengadakan penyesuaian diri dengan baik. (Bimo Walgito, 2002: 5). Jadi bimbingan adalah proses pemberian bantuan terhadap individu yang sedang membutuhkannya agar dapat memahami dirinya sendiri dan mampu menyelesaikan masalahnya dengan baik.

Adapun yang dimaksud dengan bimbingan pra nikah adalah pemberian bantuan berupa penasehatan, bimbingan dan pengarahan tentang pernikahan kepada calon pasangan suami istri sebelum melakukan akad nikah atau perjanjian yang dilakukan oleh seorang ahli (penyuluh). Adapun yang menjadi dasar dari pelaksanaan bimbingan pra nikah adalah Alqur'an dan Al-Hadist sebagai pedoman hidup yang mengatur perilaku manusia untuk kebahagiaan di dunia dan di akhirat. Kedua dasar hukum tersebut di dalamnya mengandung ajaran yang bertujuan membimbing ke arah kebaikan menjauhkan manusia dari kesesatan.

Keluarga merupakan konsep yang bersifat multidimensi para ilmuan sosial bersilang pendapat mengenai rumusan definisi keluarga yang bersifat universal. Salah satu ilmuan yang permulaan mengkaji keluarga adalah George Murdock dalam bukunya social structure, Murdock menguraikan bahwa keluarga adalah kelompok sosial yang memiliki karakteristik tunggal bersama, terdapat kerjasama ekonomi dan terjadi proses reproduksi. (Sri Lestari, 2012: 3)

Keluarga adalah elemen terkecil yang membentuk keluarga yang pada umumnya terdiri dari suami, istri dan anak-anak. Mereka biasanya menempati suatu rumah yang dipimpin oleh suami atau ayah dari anak-anak mereka. Keluarga 
suatu unit terkecil dari masyarakat yang terdiri atas kepala keluarga dan tinggal disatu atap yang sama dengan saling bergantung satu sama lainnya. (Muhammad Shalih al-Munajid: 03)

Pengertian keluarga sakinah jika diambil dari ayat 21 Ar-Rum dapat dipahami bahwa tujuan keluarga adalah untuk mencapai ketentraman dan kebahagiaan dengan dasar kasih sayang dan setiap anggota keluarga merasa aman, tentram, tenang, damai, bahagia, sejahtera serta dinamis menuju kehidupan yang baik di dunia dan akherat. Mawaddah menurut segi bahasa yang artinya "cinta". Istilah ini bermakna bahwa seseorang yang memiliki cinta di hatinya akan lapang dadanya, penuh harapan, dan jiwanya akan selalu berusaha menjauhkan diri dari keinginan buruk atau jahat. Ia akan senantiasa menjaga cinta baik di kala senang maupun susah atau sedih. Mawaddah mengandung unsur-unsur kekuatan, keinginan dan harapan pada kebaikan, serta dukungan dan perhatian. Mawaddah membuat sepasang suami istri saling menghendaki satu sama lain, saling memperhatikan dan saling mendukung dalam kebaikan. Rahmah secara sederhana dapat di artikan "kasing sayang". Istilah ini bermakna keadaan jiwa yang terpenuhi dengan kasih sayang. Rasa kasih sayang ini menyebabkan seseorang akan berusaha memberikan kebaikan, kekuatan, dan ketulusan dalam menyayangi seseorang. Keharmonisan sejati yang dilandasi rahmah membuat pasangan suami istri atau antar anggota keluarga saling menaruh iba dan belas kasih, saling menaruh simpati dan perhatian, saling memaafkan, saling menjaga, saling mengawasi dan saling melindungi. (Muhammad Shalih al-Munajid: 45)

Ciri-ciri Keluarga Sakinah: Masyarakat indonesia mempunyai istilah yang beragam terkait dengan keluarga yang ideal. Ada yang menggunakan istilah keluarga sakinah, keluarga sakinah mawaddah warahmah (keluarga samara), keluarga sakinah mawaddah warahmah dan berkah, keluarga maslahah, keluarga sejahtera, dan lain-lain. Berikut ini disajikan tiga pendapat tentang ciri-ciri keluarga yang ideal tersebut.

Pertama, ada yang berpendapat bahwa ciri keluarga sakinah mencakup hal-hal sebagai berikut:

a. Berdiri di atas fondasi keimanan yang kokoh.

b. Mentaati ajaran agama.

c. Saling mencintai dan menyayangi.

d. Saling menjaga dan menguatkan dalam kebaikan.

e. Saling memberikan yang terbaik untuk pasangan.

f. Musyawarah menyelesaikan permasalahan.

g. Kompak mendidik anak-anak.

Kedua, Organisasi Muhammadiyah menggunakan istilah keluarga sakinah yang dipahami sebagai keluarga yang setiap anggotanya senantiasa mengembangakan kemampuan dasar fitrah kemanusiaanya, dalam rangka menjadikan dirinya sendiri sebagai manusia yang memiliki tanggung jawab atas 
kesejahteraan sesama manusia dan alam, sehingga anggota keluarga tersebut selalu merasa aman, tentram, damai, dan bahagia. Lima cirinya adalah sebagai berikut:

a. Kekuatan/kekuasaan dan keintiman (power and intimacy).

b. Kejujuran dan kebebasan berpendapat (honesty and freedom of expression).

c. Kehangatan, kegembiraan, dan humor (warmth, joy and humor).

d. Keterampilan organisasi dan negosiasi (organization and negotiating).

e. Sistem nilai (value system) yang menjadi pegangan bersama.

Ketiga, Nahdlatul Ulama menggunakan istilah keluarga maslahah (Mashalihul Usrah), yaitu keluarga yang dalam hubungan suami-istri dan orang tua-anak menerapkan prinsip-prinsip keadilan (i'tidal), keseimbangan (tawazzun), moderat (tawasuth), toleransi (tasamuh) dan amar ma'ruf nahi munkar; berakhak karimah; sakinah mawaddah wa rahmah; sejahtera lahir batin, serta berperan aktif mengupayakan kemaslahatan lingkungan sosial dan alam sebagai perwujudan islam rahmatan lil'alamin. (Subdit Bina Keluarga Sakinah Direktorat Bina KUA \& Keluarga Sakinah Ditjen Bimas Kemeg RI, 2017 : 12-14)

Upaya Membina Keluarga Sakinah: Setelah suami istri memahami hak dan kewajibannya, kedua belah pihak masih harus melakukan berbagai upaya yang dapat mendorong ke arah tercapainya cita-citan mewjudkan keluarga sakinah. Secara singkat dapat dikemukakan di sini beberapa upaya yang perlu ditempuh guna mewujudkan cita-cita kearah tercapainya cita-cita keluarga sakinah. Upaya tersebut antara lain:

1. Mewujudkan Harmonisasi Hubungan antara Suami Istri

Upaya mewujudkan harmonisasi hubungan suami istri dapat dicapai antara lain melalui:

a. Adanya saling pengertian.

b. Saling melakukan penyesuaian diri.

c. Memupuk rasa cinta.

d. Melaksanakan asas musyawarah.

e. Suka memaafkan.

2. Membina Hubungan antara Anggota Keluarga dan Lingkungan

Keluarga dalam lingkupyang lebih besar tidak hanya terdiri dari ayah, ibu dan anak akan tetapi tetap menyangkut hubungan persaudaraan yang lebih besar lagi, baik hubungan antara anggota kleuarga maupun hubungan dengan lingkungan masyarakat.

a. Hubungan Antara Anggota Keluarga

Karena hubungan persaudaraan yang lebih luas menjadi ciri dari masyarakat kita, hubungan antara bersama keluarga besar harus terjalin dengan baik antara keluarga dari kedua belah pihak.

b. Hubungan Dengan Tetangga dan Masyarakat

Tetangga merupakan orang-orang yang terdekat yang umumnya merekalah orang-orang yang pertama tahu dan dimintai pertolongan. 
3. Melaksanakan Pembinaan Kesejahteraan Keluarga

Dalam membina kebahagiaan dan kesejahteraan keluarga ada beberapa upaya yang dapat ditempuh, antara lain dengan cara melakukan:

a. Sepuluh Program Pokok Pembinaan Kesejahteraan Keluarga:

1) Sandang;

2) Pangan;

3) Pendidikan dan keterampilan;

4) Kesehatan; dan

5) Perencanaan sehat.

b. Keluarga Berencana

Keluarga berencana merupakan salah satu upaya mewujudkan kebahagiaan dan kesejahteraan keluarga. Tujuan utama dari KB adalah untuk lebih meningkatkan kesejahteraan ibu dan anak.

c. Usaha Perbaikan Gizi Keluarga

Dalam upaya mewujudkan kebahagiaan dan kesejahteraan keluarga, gizi memegang peranan yang sangat penting.

4. Membina Kehidupan Beragama Dalam Keluarga

Setiap anggota keluarga, terutama orang dituntut untuk senantiasa bersikap dan berbuat sesuai garis-garis yang diterapkan oleh Allah dan Rasul-Nya. Dengan demikian diharapkan setiap anggota keluarga memiliki sifat dan budi pekerti yang luhur yang sangat diperlukan dalam kehidupan berkeluarga dan bermasyarakat. (Direktorat Jenderal Bimbingan Masyarakat Islam dan Penyelenggaraan Haji, 2003: 25-48)

Dengan ini mengharuskan setiap pasangan suami istri memiliki sifat yang penyayang dan murah hati. Ketika melihat pasangan kita membuat kesalahan juga mengharuskan sabar, tidak pemarah, serta tidak ada rasa dendam ketika pasangannya membuat kesalahan. Namun tetapi sekaligus menuntut seseorang memiliki ketegasan, kekuatan dan keteguhan ketika harus melindungi pasangannya hal keburukan atau kejahatan orang lain.

Berdasarkan pengamatan di KUA Jamblang bahwa dalam pemberian bimbingan terhadap calon pasangan untuk mewujudkan keluarga sakinah mawaddah dan rahmah sudah dilaksanakan dengan baik namun pada kenyataanya ada beberapa calon pasangan yang tidak dapat hadir atau mengikuti bimbingan pra nikah dengan berbagai alasan. Dengan adanya bimbingan pra nikah diharapkan tujuan dari pernikahan yang akan dilakukan oleh calon pasangan bisa dipahami dan dijalankan dengan baik,sehingga dapat terwujudnya keluarga yang diharapkan yaitu keluarga yang sakinah mawaddah rahmah.

\section{METODE PENELITIAN}

Dalam penelitian ini, jika dilihat dari jenis penelitian yakni termasuk jenis penelitian kualitatif, karena penelitian ini dilakukan pada kondisi yang alamiah dan apa adanya (Sugiyono, 2008 :8). Penelitian ini dilakukan pada objek yang alamiah 
yakni obyek yang berkembang apa adanya dan tidak dimanipulasi oleh peneliti. Dengan ini peneliti akan mengetahui fenomena-fenomena yang ada. Adapun dengan tujuan penelitian lapangan adalah untuk mempelajari secara intensif tentang latar belakang keadaan sekarang, dan interaksi lingkungan sesuatu urut sosial: individu, kelompok, lembaga, atau masyarakat (Sumadi Suryabrata, 2005: 80)

Metode yang digunakan dalam penelitian ini adalah metode kualitatif yaitu metode penelitian yang berlandaskan pada filsafat. Post positivisme, digunakan untuk meneliti pada kondisi objek yang alamiah, dimana peneliti adalah sebagai instrumen kunci, pengambilan sampel sumber data dilakukan secara trianggulasi (gabungan observasi, wawancara, dokumentasi), data yang diperoleh cenderung data kualitatif, analisis data bersifat induktif, dan hasil penelitian kualitatif bersifat untuk menemukan hipotesis. (Sugiyono, 2017: 9-10).

Variabel penelitian sangat menentukan bentuk atau jenis pendekatan, jenis pendekatan juga tidak dapat diabaikan peranannya dalam menentukan perincian secara teliti (Suharsimi Arikunto, 2006: 82). Dapat dilihat dari pengangkatan masalah yang diambil oleh peneliti bahwa penelitian ini termasuk jenis pendekatan deskriptif. Deskriptif adalah data yang dikumpulkan itu berupa kata-kata dan gambaran. Hal itu disebabkan oleh adanya penerapan metode kualitatif. Selain itu, semuanya yang dikumpulkan berkemungkinan menjadi kunci terhadap apa yang sudah diteliti. Tujuan penelitian ini adalah mengungkapkan fakta, keadaan, fenomena, variabel dan keadaan yang terjadi saat penelitian berjalan dan menyuguhkan apa adanya (Lexy J. Moleong, 2014: 11). Dengan demikian peneliti dapat mendeskripsikan atas dasar fenomena yang dijumpai di lapangan.

Yang dimaksud dengan sumber data dalam suatu penelitian adalah subyek dari mana data-data itu dapat diperoleh (Suharsimi Arikunto, 2006: 129). Mengenai sumber data penelitian ini dibagi atas 2 jenis: data primer dan data sekunder. Lalu teknik pengumpulan data yang digunakan peneliti adalah trianggulasi (gabungan observasi, wawancara, dan dokumentasi). Guna memperoleh data yang diperlukan yang berhubungan dengan penelitian ini, digunakan teknik-teknik pengumpulan data sebagai berikut: wawancara, observasi, dan studi dokumentasi. Teknik analisis data menggunakan Menurut Miles and Huberman bahwa teknik analisis data yaitu dilakukan secara interaktif melalui proses data reduction, data display dan verification (Sugiyono, 2016: 401)

\section{HASIL PENELITIAN}

\section{A. Peran BP4 dalam Memberikan Bimbingan Pranikah dalam Mewujudkan Keluarga Sakinah Mawaddah Rahmah}

Salah satu cita-cita perkawinan adalah membentuk keluarga yang sakinah, mawaddah, dan rahmah. Cita-cita tersebut tentu menjadi harapan bagi setiap pasangan suami istri dalam membina kehidupan keluarga., terkadang istri citacita tersebut tidak begitu saja tercapai dengan mudah Namun. Karena setiap kehidupan yang dijalani akan selalu dihadapi dengan berbagai persoalan, baik 
persoalan yang berasal dari diri sendiri maupun yang berasal dari lingkungan keluarga.

Menurut peneliti bahwa tujuan perkawinan tersebut mustahil dapat tercapai jika pasangan calon pengantin kudang memiliki bakat dalam mengarungi bahtera rumah tangganya. Oleh karenanya perlu persiapan sejak dini, bahwa pengetahuan tentang pengertian pernikahan, tujuan dan mengetahui peran masing-masing antara suami istri mutlak dibutuhkan bimbingan pra nikah. Dalam bimbingan pra nikah dijelaskan kewajiban suami terhadap istri dan sebaliknya, kewajiban isteri terhadap suami. Kewajiban suami sebagai kepala keluarga harus melayani suami, menerima dan menghormati pemberian suami walaupun sedikit, serta mencukupkan nafkah yang diberikan suami dengan kekuatan dan kemampuan mengatur dan mengurus rumah tangga dan menjadikan rumah tangga bahagia dunia dan akhirat.

Tahap pemberian bimbingan yang dilakukan oleh KUA. Melalui bimbingan pra nikah kepada para calon pengantin yang akan membentuk rumah tangga, dimaksudkan agar mereka memahami secara benar peran masing-masing dalam kehidupan rumah tangga dan menginsyafi tanggung jawab masing-masing dalam menciptakan kebahagiaan hidup rumah tangga. Dan calon pengantin akan membina keluarga mereka dengan benar karena bekal sebelum menikah sudah diberikan oleh para calon pembimbing. Berikut kutipan wawancara pribadi peneliti dengan Tatang.

"Sebelum melaksanakan perkawinan, pihak KUA memberikan bimbingan pra nikah terhadap kedua calon pasangan. Materi yang diberikan pada saat Bimbingan Konseling Pra Nikah diantaranya Undang-Undang Nomor 1 Tahun 1974 tentang perkawinan, pemantapan keluarga sejahtera dan kesehatan. Hal ini melibatkan unsur dari Puskesmas, unsur dari MUI, dan unsur dari Pandaka. Berbagai faktor akan disampaikan pada calon pasangan diantaranya kesehatan. Dijelaskan tentang gizi, reproduksi, dampak perkawinan di usia muda dan sisi keagamaan disampaikan oleh MUI, bahwa calon pasangan mempunyai bekal dalam menjalankan rumah tangga, maksudnya dalam hal ini berupa fiqih-fiqih munakahat yang berkenaan dengan mandi zunub, adab bersetubuh dan yang berhubungan dengan suami istri. Kemudian dibekali dengan metode-metode yang sifatnya itu psikologis dalam rumah tangga karena dalam membina keluarga tidak sulit dan tidak mudah juga, tapi kembali pada individunya sendiri.Jadi diadakannya bimbingan pra nikah ini sangat penting agar masyarakat yang mengikuti bimbingan tersebut mempunyai bekal untuk membina keluarga yang sakinah mawaddah dan rahmah. "(Wawancara pribadi dengan Tatang / Kepala Kantor Urusan Agama Jamblang, 20 Mei 2018).

Dengan demikian harapan lembaga dengan diadakannya bimbingan pra nikah agar bermanfaat bagi calon pengantin ke depannya agar dapat membangun rumah tangga yang sakinah mawaddah dan rahma.Yang paling utama terhindarnya dari perceraian, karena dampak dari perceraian sangat banyak terutama pada anak. Jadi harapan lembaga untuk tercipta keluarga yang 
sakinah mawaddah dan rahma kembali lagi kepada individunya masing-masing bagaimana cara mengaplikasikan materi-materi atau informasi yang mereka fahami dari bimbingan pra nikah. (Hasil pengamatan peneliti saat mengunjungi lokasi di Kantor Urusan Agama (KUA) Jamblang tanggal 03 Agustus 2018). Di samping itu untuk menjadi keluarga sakinah, calon pengantin harus memiliki sebuah dasar konsepsi mawaddah dan rahmah, suasana cinta kasih diantara keduanya.Oleh karenanya ketika mencari pasangan hidup, syarat yang penting dan tidak dapat dilupakan begitu saja adalah calon pasangan yang saleh dan salehah. Dengan begitu akan mudah dibentuk sebuah rumah tangga yang penuh berkah, sehingga dalam perjalannya sebuah keluarga tidak mudah terseret arus perubahan jaman. Dan yang terpenting adalah tetap berpegang teguh pada tali agama. Jika hal ini dapat dilakukan bukan tidak mungkin dalam keluarga akan tercipta keharmonisan dan kedamaian.

Adapun bimbingan pra nikah dalam membantu masyarakat menciptakan keluarga sakinah mawaddah dan rahmah merupakan upaya preventif yang dilakukan KUA sebelum adanya perkawinan. Upaya ini sangat besar manfaatnya karena upaya dalam menjalankan kehidupan setelah perkawinan pasangan suami istri tersebut sudah dibekali dengan pengetahuan tentang perkawinan. Berikut kutipan wawancara peneliti dengan H. Muhaemin yang merupakan salah satu seorang narasumber.

"Peran BP4 KUA Jamblang dalam memberikan bimbingan pra nikah dalam mewujudkan keluarga sakinah mawaddah dan rahmah diantaranya memberikan pengetahuan tentang keluarga, memberikan gambaran tentang bagaimana contoh keluarga yang ada di sekitar kita, memberikan pemahaman tentang pendidikan keagamaan bagi calon pengantin, kemudian memberikan peranan masing-masing calon pengantin ketika sudah berkeluarga apakah pertanggung jawab menjadi ibu rumah tangga." (Wawancara pribadi dengan H. Muhaemin / Penyuluh Kantor Urusan Agama (KUA), 03 Agustus 2018)

Agar hubungan perkawinan tetap terpelihara dan hidup dengan suasana yang harmonis sakinah, mawaddah dan rahmah, peningkatan terhadap kualitas dan nilai rumah tangga diharapkan dapat menekan terjadinya perceraian. Suatu krisis yang berakhir dengan perceraian khususnya terjadi karena tidak adanya keharmonisan dalam rumah tangga itu disebabkan oleh beberapa faktor. Untuk itu perlu adanya bimbingan yang berkesinambungan dan tak ada hentinya dari petugas BP4 demi terwujudnya suatu rumah tangga yang sakinah mawaddah dan rahmah. Berikut kutipan wawancara peneliti dengan Khidir.

"Peran BP4 dalam mewujudkan keluarga sakinah mawaddah dan rahmah diantaranya dengan melalui pemberian nasihat dan bimbingan kepada calon pengantin yang akan membentuk rumah tangga tahap pemberian penasihatan dan penyuluhan yang diberikan pada pasangan yang akan membentuk rumah tangga, dimaksudkan agar mereka memahami secara benar peran masingmasing dalam kehidupan rumah tangga, selain itu dengan adanya peran BP4 
dapat mengurangi angka perceraian dan meningkatkan kualitas perkawinan serta menjawab kebingungan dari calon pengantin itu sendiri. (Wawancara pribadi dengan Khidir / Ketua BP4 Kantor Urusan Agama (KUA), 03 Agustus 2018.

\section{B. Metode yang Digunakan BP4 dalam Mewujudkan Keluarga Sakinah Mawaddah Rahmah}

Metode yang digunakan oleh BP4 Kantor Urusan Agama Jamblang dalam kegiatan bimbingan konseling pranikah adalah menggunakan metode ceramah dan tanya jawab. Metode ceramah dan tanya jawab pada dasarnya sering digunakan dalam berbagai kegiatan baik kegiatan belajar mengajar maupun kegiatan-kegiatan lainnya termasuk kegiatan bimbingan konseling pranikah. Dengan metode ceramah dan tanya jawab dipilih karena mempermudah dalam penyampaian materi, khususnya materi yang disampaikan dalam kegiatan bimbingan pranikah.

Agar hubungan perkawinan tetap terpelihara dan hidup dengan suasana yang harmonis, sakinah, mawaddah dan rahmah peningkatan terhadap kualitas dan nilai rumah tangga diharapkan dapat menekan terjadinya perceraian. Suatu krisis yang berakhir dengan perceraian biasanya terjadi karena tidak keharmonisan dalam rumah tangga itu disebabkan oleh beberapa faktor untuk itu perlu adanya bimbingan yang berkesinambungan dan tak ada hentinya dari petugas BP4 demi terwujudnya suatu rumah tangga yang sakinah, mawaddah dan rahmah. Untuk dapat mewujudkan keluarga yang sakinah, mawaddah dan rahmah BP4 menggunakan beberapa metode. Berikut kutipan wawancara peneliti dengan $\mathrm{H}$. Muhaemin yang merupakan salah seorang narasumber:

"Metode yang dilakukan oleh BP4 terhadap calon pengantin diantaranya ceramah dan tanya jawab. Dengan metode ceramah, pihak BP4 memberikan materi kepada calon pengantin atau calon peserta bimbingan kaitannya dengan peran serta keluarga, bagaimana cara membina keluarga, membina anak, bagaimana agar keluarga tetap utuh ketika ada masalah besar jangan dibesarbesarkan, ketika ada masalah kecil dihilangkan. Itu salah satu penyampaian metode yang digunakan oleh pemateri."

Dengan menggunakan metode ceramah diharapkan agar calon pasangan dapat mengerti dan memahami tentang isi dari materi yang disampaikan oleh pemateri. Selain menggunakan metode ceramah pemateri juga menggunakan metode tanya jawab. Penggunaan metode tanya jawab dimaksudkan untuk memberi kesempatan kepada peserta bimbingan untuk bertanya atau memberikan jawaban atas pertanyaan pembimbing. Sebagaimana yang telah disampaikan oleh H. Muhaemin, yakni :

"Metode tanya jawab ketika ada peserta dari calon pra nikah bertanya kepada narasumber kaitannya dengan apa yang akan dihadapi nanti ketika sudah menjadi keluarga, artinya ketika dia sudah menikah baru mereka memahami tentang peran dari masing-masing keluarga. Kemudian materinya itu disamping dari kesehatan juga dari PLKB dan Majelis Ulama 
juga dari KUA yang hal ini oleh pihak BP4 dan pihak pelaksana bimbingan konseling kepada peserta bimbingan.Waktunya itu kurang lebih dua hari, jadi mereka diundang oleh pihak BP4 kemudian kami di sini menyediakan tempat dan tidak ada biaya dan hanya untuk datang dan akan mendapatkan piagam bimbingan dari BP4." (Wawancara pribadi dengan $\mathrm{H}$. Muhaemin/Penyuluh Kantor Urusan Agama (KUA), 03 Agustus 2018).

Seperti yang sudah disampaikan bahwasanya metode tanya jawab ini untuk mempermudah calon pasangan untuk menanyakan apabila ada yang tidak dimengerti agar bertanya kepada pemateri. Cara ini digunakan untuk menggali informasi mengenai tingkat pemahaman peserta tentang hukum perkawinan dan tujuan mengikuti bimbingan pranikah.

\section{Dampak Bimbingan Pranikah dalam Mewujudkan Keluarga Sakinah Mawaddah Rahmah}

Kegiatan bimbingan pra nikah diadakan dengan tujuan agar mempersiapkan calon pasangan agar benar-benar siap dalam mengarungi bahtera rumah tangga, dengan kata lain kegiatan bimbingan pra nikah bertujuan untuk meningkatkan kualitas perkawinan serta mengurangi angka perceraian. Tingginya angka perceraian yang sangat memperhatinkan dengan ini adanya bimbingan pra nikah agar meningkatkan kualitas perkawinan dan menjadikan rumah tangga yang harmonis dan menuju dalam keluarga sakinah mawaddah rahmah.

Sebagaimana yang disampaikan oleh Pak H. Muhaemin selaku penyuluh, yaitu:

"Dampak dari bimbingan tersebut ada manfaatnya salah satunya itu ketika calon pasangan dapat memahami bagaimana teori-teori tentang keluarga, sehingga calon pasangan mau menerima materi dan dapat pemahaman tentang bagaimana membina keluarga kemudian mereka juga dapat menambah pengalaman karena bisa bertemu dengan teman-teman peserta lainnya, bisa saling bertanya, bertukar fikiran, sehingga calon pasangan dapat menambah wawasan dan pengalaman itu salah satu dampak dari dilaksanakanya bimbingan konseling pra nikah itu diharapkan akan terwujudnya keluarga yang memiliki pengetahuan dan wawasan dalam membina rumah tangga." (Wawancara pribadi dengan H. Muhaemin / Penyuluh Kantor Urusan Agama (KUA), 03 Agustus 2018).

Adapun dampak bimbingan konseling pra nikah dalam mewujudkan keluarga sakinah, mawaddah dan rahmah di Kantor Urusan Agama (KUA) Jamblang diantaranya adalah:

1. Mengurangi angka perceraian dan meningkatkan kualitas perkawinan

Bimbingan pranikah bagi calon pengantin, menjadi sangat penting dilakukan. Dimaksudkan agar pasangan memahami secara benar peran masing-masing 
dalam kehidupan rumah tangga dan bisa bermanfaat ke depannya untuk mereka membangun keluarga sakinah, mawaddah dan rahmah sehingga dapat terhindar dari perceraian. Bimbingan pra nikah dalam membantu masyarakat menciptakan keluarga sakinah, mawaddah dan rahmah yang dilakukan KUA sebelum adanya perkawinan. Bimbingan pra nikah ini sangat besar manfaatnya supaya dalam menjalankan perkawinan pasangan suami istri sudah dibekali pengetahuan tentang perkawinan dan hubungan perkawinan tetap terpelihara dan hidup dengan suasana yang harmonis sakinah, mawaddah dan rahmah, sehingga dapat meningkatkan kualitas dan nilai rumah tangga nanti.

2. Dengan dilakukanya bimbingan pra nikah berdampak baik bagi calon pasangan karena dengan adanya bimbingan pra nikah tersebut calon pasangan dapat memahami dan menambah wawasan pengetahuanya tentang materi keluarga, bagaimana membina keluarga yang baik, bagaimana adabnya bersetubuh, lalu memahami cara menyelesaikan masalah dengan baik, serta dengan mengikuti bimbingan pra nikah calon pasangan mendapatkan bekal agar bisa mewujudkan keluarga yang sakinah mawaddah dan rahmah.

\section{PEMBAHASAN}

Menurut pengamatan peneliti, di Kantor Urusan Agama (KUA) Jamblang pelaksanaan bimbingan pra nikah sudah dilaksanakan secara optimal, tetapi karena calon pasangan pengantin tidak dapat hadir dalam pelaksanaan bimbingan pra nikah dimana salah satu pasangan calon pengantin tidak dapat hadir dikarenakan bekerja di luar kota. Masyarakat tidak antusias terhadap adanya bimbingan pra nikah, mereka beranggapan bimbingan pra nikah dianggap merepotkan dan menghambat proses perkawinan. Pada dasarnya bimbingan pra nikah bagi para calon penganting menjadi sangat penting dilakukan dan dapat dijadikan bekal agar dapat mempersiapkan calon keluarga sakinah. Seharusnya dari masing-masing petugas KUA dapat memberikan penyuluhan lebih banyak kepada calon pengantin tentang pentingnya bimbingan pra nikah sehingga pelaksanaan bimbingan pra nikah dapat dilaksanakan secara optimal. Dalam bimbingan pra nikah, calon pengantin yang telah mengeluh bimbingan pra nikah diberikan sertifikat sebagai tanda bukti kelulusan.

Hasil wawancara peneliti dengan H. Muhaemin, seluruh penyuluh di KUA Jamblang membenarkan bahwa pasangan yang tidak mengikuti bimbingan pra nikah atau tidak mempunyai sertifikat tersebut masih diperbolehkan untuk melangsungkan pernikahan karena pihak KUA belum berani untuk menerapkan melarang pasangan yang tidak ada sertifikat bimbingan pra nikah untuk menikah. Jika melarang pasangan untuk menikah karena dia belum mengikuti bimbingan pra nikah maka kami dapat dituntut atau dipidanakan karena aturannya pasangan tersebut telah memenuhi syarat-syarat yang sudah ada di dalam ketentuan undangundang.Jadi apabila mau diterpkan seperti itu sertifikat bimbingan pra nikah menjadi syarat untuk melangsungkan pernikahan. Belum adanya peraturan yang 
resmi tentang keikutsertaan dalam bimbingan pra nikah menyebabkan tidak semua calon pengantin mengikuti program tersebut, sehingga informasi tentang kehidupan pernikahan yang sehat, harmoni dan sesuai dengan ajaran-ajaran agama, belum didapatkan oleh calon pengantin yang seharusnya menjadi bekal mereka dalam membentuk keluarga sakinah, mawaddah dan rahmah. Peran BP4 dalam mewujudkan keluarga sakinah, mawaddah dan rahmah sangat berperan penting dimana peran BP4 sendiri dapat mengurangi angka perceraian. BP4 bertugas dalam mewujudkan keluarga sakinah mawaddah dan rahmah.

\section{SIMPULAN}

Dari hasil penelitian dan pembahasan tentang peran BP4 dalam memberikan bimbingan pra nikah dalam mewujudkan keluarga sakinah, mawaddah dan rahmah di Kantor Urusan Agama (KUA) Jamblang, maka penulis menyimpulkan sebagai berikut.

1. Peran BP4 bimbingan pra nikah guna mewujudkan keluarga sakinah, mawaddah, dan rahmah yang berlangsung di KUA Jamblang adalah sebagai pencapaian informasi kepada masyarakat dan pemberian nasihat atau yang disebut dengan bimbingan pra nikah.

2. Adapun metode yang digunakan dalam bimbingan pra nikah oleh petugas KUA Jamblang adalah ceramah dan tanya jawab, dengan memberikan materi kepada calon pengantin seputar cara membina keluarga, peran serta keluarga, membina anak dengan baik, dan calon pengantin bertanya seputar apa yang dihadapi nanti ketika sudah menikah.

3. Dampak bimbingan konseling pra nikah dapat mengurangi angka perceraian di masyarakat dan meningkatkan kualitas perkawinan. Selain itu, dapat memberikan pemahaman dan bekal untuk calon pasangan mengenai materi keluarga agar tercapainya membentuk keluarga yang sakinah, mawaddah, dan rahmah.

\section{DAFTAR PUSTAKA}

Abdulsyani. (2012). Sosiologi: Skema, Teori, dan Terapi. Jakarta: PT. Bumi Aksara

Al-munajid, Mohammad Shalih. Tuntunan Menggapai Kelurga Sakinah: Pustaka Ibnu Umar

Amin Munir Samsul (2013). Bimbingan dan Konseling Islam. Jakarta: Amzah.

Direktur Bina KUA dan Keluarga Sakinah (2017). Fondasi Keluarga Sakinah. Jakarta: Subit Bina Keluarga Sakinah Direktorat Bina KUA dan Keluarga Sakinah Ditjen Bimas Kemenag RI.

http://www.bahanpustaka.blogspot.co.id Diakses pada tanggal 5 februari 2018, pukul 11.07 
Lestari, Sri. (2012). Psikologi Keluarga. Yogyakarta: Kencana Prenada Media Group

Moleong J. Lexy. (2004). Metodologi Penelitian Kualitatif. Bandung: PT. Remaja Rosdakarya.

Sugiyono. (2008). Metode Penelitian Kuantitatif, Kualitatif dan R\&D. Bandung: Alfabeta.

Sugiyono (2016). Metode Penelitian Pendidikan. Bandung: Alfabeta

Sugiyon. (2017). Metode Penelitian Kualitatif. Bandung: Alfabeta

Suharsimi Arikunto. (2006). Prosedur Penelitian Suatu Pendekatan Praktik. Jakarta: PT. Rineka Cipta.

Undang-Undang Nomor 1 Tahun 1974 Tentang Perkawinan

Walgito, Bimo. (2002). Bimbingan Dan Konseling Perkawinan. Yogyakarta: Andi Ofset 